\title{
Toxicological properties of an aqueous extract of Aristolochia triangularis leaves, using the brine shrimp lethality and Allium cepa bioassays
}

\author{
José Darlan Alves da Silva ${ }^{1}$ Cláudio Rodrigo Nogueira ${ }^{2 *}$ iD Maria do Carmo Vieira ${ }^{3}$ \\ Silvia Cristina Heredia-Vieira ${ }^{1}$ Alexeia Barufatti ${ }^{4}$ iD Bruno do Amaral Crispim ${ }^{4}$ \\ Luiza Flávia Veiga Francisco ${ }^{2}$ Lucilene Finoto Viana ${ }^{1}$ Claudia Andrea Lima Cardoso ${ }^{1}$
}

${ }^{1}$ Programa de Pós-graduação em Recursos Naturais (PGRN), Universidade Estadual de Mato Grosso do Sul (UEMS), Dourados, MS, Brasil. ${ }^{2}$ Faculdade de Ciências Exatas e Tecnologia (FACET), Universidade Federal da Grande Dourados (UFGD), 79804-970, Dourados, MS, Brasil E-mail: claudiornogueira@ufgd.edu.br. "Corresponding author.

${ }^{3}$ Faculdade de Ciências Agrárias (FCA), Universidade Federal da Grande Dourados (UFGD), Dourados, MS, Brasil.

${ }^{4}$ Faculdade de Ciências Biológicas e Ambientais (FCBA), Universidade Federal da Grande Dourados (UFGD), Dourados, MS, Brasil.

ABSTRACT: The aqueous extract of Aristolochia triangularis leaves showed activity against Artemia salina larvae, with an LD ${ }_{50}$ of $370.6 \mu g$ / $m L$. In experiments with Allium cepa seeds, the extract caused a $51.26 \%$ reduction in the germination index, inhibited mean root growth, and was cytotoxic at concentrations of 668 and 2,000 $\mu \mathrm{g} / \mathrm{mL}$. Its antioxidant activity was additionally assessed in this research and the ferric reducing antioxidant power value was found to be $391.2 \mu \mathrm{M} / \mathrm{g}$. Such health-beneficial property can be attributed partly to the total phenolic content, spectrophotometrically determined as $52.67 \mathrm{mg} / \mathrm{g}$. The occurrence of cytotoxicity suggested caution when consuming teas from A. triangularis leaves for medicinal purposes, and equally reveals the need for further studies to investigate their adverse effects.

Key words: cipó-mil-homens, infusion, toxicity.

Propriedades toxicológicas de um extrato aquoso de folhas de Aristolochia triangularis utilizando os bioensaios de letalidade com Artemia salina e Allium cepa

RESUMO: $O$ extrato aquoso de folhas de Aristolochia triangularis mostrou atividade sobre larvas de Artemia salina, com um DL ${ }_{50}$ de 370,6 $\mu \mathrm{g} / \mathrm{mL}$. Em experimentos com sementes de Allium cepa, o extrato provocou uma redução de 51,26\% no índice de germinação, inibiu o crescimento radicular médio e foi citotóxico nas concentrações de 668 e $2.000 \mu \mathrm{g} / \mathrm{mL}$. Sua atividade antioxidante foi adicionalmente avaliada nesta pesquisa e o valor de poder redutor de ions férrico foi de 391,2 $\mu \mathrm{M} / \mathrm{g}$. Tal propriedade benéfica para a saúde pode ser parcialmente atribuída ao conteúdo de compostos fenólicos totais, espectrofotometricamente determinada como 52,67 mg/g. A ocorrência de citotoxicidade sugeriu cautela ao consumir chás de folhas de A. triangularis para propósitos medicinais, e igualmente revela a necessidade por estudos adicionais para investigar os efeitos adversos deles.

Palavras-chave: cipó-mil-homens, infusão, toxicidade.

\section{INTRODUCTION}

Aristolochia spp. (Aristolochiaceae), widely used in homeopathy and traditional medicine, contains numerous bioactive compounds, and are chemically characterized by the predominance of lignoids, terpenoids, alkaloids, alkamides, flavonoids, and nitrophenanthrene derivatives (LOPES et al., 2001).

Aristolochia triangularis Cham., a woody liana, is 1 of the 92 known Brazilian Aristolochia species (BARROS et al., 2015). It is among the most cited plants within the ethnobotanical sector of the South Region of Brazil, and has been used for treating several disease conditions such as diabetes, rheumatism, infections, and wounds and skin diseases (HEINRICH et al., 2009; TROJANRODRIGUES et al., 2012; PEREIRA et al., 2018; VIBRANS et al., 2018).

Based on its ethnopharmacological uses, extensive studies investigating the therapeutic potentials and biosafety of this species have been carried out and reported. The dichloromethane extract of $A$. triangularis roots have been shown to possess an anti-inflammatory efficacy similar to that of phenylbutazone (MUSCHIETTI et al., 1996). 
Conversely, organic extracts from aerial parts of this plant have been shown to exhibit significant cytotoxicity and DNA interaction (MONGELLI et al., 2000). Other evidence indicated the cytological effects of infusions from $A$. triangularis branches and decoctions from secondary growth stems, on the cell cycle of Allium cepa L. meristems (SCHVARTZMAN et al., 1977; AMAT et al., 2002), and the anti-mycobacterial activity of hydroalcoholic drinks prepared from $A$. triangularis (OLIVEIRA et al., 2007). In addition, a recent study demonstrated that the methanol extract from the rhizomes and roots of this species and some compounds isolated from it had promising bioactivities against microbial pathogens, in certain cases comparable or better than those of existing commercial drugs (ampicillin and chloramphenicol) (PEREIRA et al., 2018).

$A$. triangularis stems, rhizomes, leaves, and roots have been chemically examined, and a total of 47 non-extractable (by steam distillation) compounds described (RÜCKER \& LANGMANN, 1978; RÜCKER et al., 1981; LOPES et al., 1990; PRIESTAP et al., 1990; LEITÃO et al., 1991; LIN et al, 1997; MICHL et al., 2016; PEREIRA et al., 2018). Among them, only the aristolactam I and aristolochic acids I, II, C and D have been reported in leaves so far (MICHL et al., 2016).

Cytotoxicity and mutagenicity studies indicated that more attention be paid to the consumption of Aristolochia spp., as evidenced by the toxicity of its representative chemical constituents, particularly those from aristolactams and aristolochic acids (MICHL et al., 2016). Incidentally, these phenanthrene derivatives have been implicated as the main active and toxic components in herbal preparations containing Aristolochia, and account for the extensive literature on this species (LOPES et al., 2001; MICHL et al., 2016). However, there are fears that such a reductionist view can be detrimental to understanding the true pharmacological significance of these plants; therefore, stimulating more detailed investigations (LOPES et al., 2001).

Overall, it can be considered that studies specific to the aqueous extracts of Aristolochia spp. are relatively scarce. Hence, the main objective of this study was to evaluate the toxicological properties of the aqueous extract of $A$. triangularis leaves, using the brine shrimp lethality and $A$. сеpa bioassays. Its ferric reducing antioxidant power, total phenolic, and total tannin content were secondarily evaluated in this research, for the only purpose of generating preliminary chemical data and mapping a possible biological activity for this extract.

\section{MATERIALS AND METHODS}

\section{General experimental procedures}

All chemical reagents and solvents were of analytical grade, purchased from Synth ${ }^{\circledR}$ or SigmaAldrich $^{\circledR}$, and used without further purification. Distilled water was obtained from a distiller, and ultrapure deionized water (resistivity of $18.2 \mathrm{M} \Omega$ ) from a Milli-Q ${ }^{\circledR}$ system (Songpa-gu, South Korea). The UV absorptions were measured on a UVVis digital spectrophotometer from Global Trade Technology. Freeze drying was carried out using a lyophilizer (CHRIST, ALPHA 1-2 LD, plus) (Spain). An ACB labor water bath (Germany) was used for temperature control. The Binocular E100 (Nikon) microscope was used to read slides.

\section{Plant material}

Plant material (leaves) was harvested from the Medicinal Plants Garden of the Federal University of Grande Dourados, Dourados, MS, Brazil, in November 2016, and identified as A. triangularis Cham. by MSc. Joelcio Freitas. A voucher specimen (MBML53232) was deposited at the herbarium of Museum of Biology Prof. Mello Leitão (MBML), in the city of Santa Teresa, Espírito Santo State, Brazil. Authorization IBAMA number 51842. Access register CGEN/MMA number A1F6637.

\section{Infusion preparation}

To prepare the infusion to $2 \%(\mathrm{w} / \mathrm{v})$, in natura leaves of $A$. triangularis (30.0 g) were selected and processed using a preliminary mechanical operation. In brief, the leaves were section-divided, immersed in pre-heated distilled water to $95^{\circ} \mathrm{C}$, and the resulting mixture allowed to rest for $15 \mathrm{~min}$ at room temperature, before being filtered through analytical filter paper. Two thirds of the aqueous solution obtained was frozen and lyophilized, successively, to give the freeze dried aqueous extract (FDAE; $1.93 \mathrm{~g} ; 6.43 \%$ ), and the left over was stored at $4{ }^{\circ} \mathrm{C}$ for the phytochemical analyses and bioassays.

\section{Toxicity and genotoxicity assays} Acute toxicity test in Artemia salina

The brine shrimp (A. salina) lethality test was performed using the Meyer method (MEYER et al., 1982). Briefly, $A$. salina cysts were incubated under artificial light $(60 \mathrm{~W})$ and aeration for $48 \mathrm{~h}$, in a synthetic sea salt solution $(20 \mathrm{~g} / \mathrm{L})$, at $\mathrm{pH} 8$, after adjusting with $\mathrm{NaHCO}_{3}$. FDAE solutions in 5 concentrations $(67,401,668,1,336$, and $2,000 \mu \mathrm{g} / \mathrm{mL})$ were prepared for this bioassay. Saline solution and 
rutin were used as negative and positive controls, respectively. Each concentration level was evaluated in triplicates with 10 larvae each. The death counts were obtained after $24 \mathrm{~h}$ of larvae-solution contact, and the acute toxicity was expressed as $\mathrm{LD}_{50}$.

\section{Allium cepa bioassay}

Tests involving $A$. cepa were performed following the protocol proposed by MATSUMOTO AND MARIN-MORALES (2005), with modifications. The FDAE was screened at the concentrations of 67, 401, 668, and $2000 \mu \mathrm{g} / \mathrm{mL}$, with distilled water and the aqueous solution of the trifluralin herbicide ( $0.84 \mathrm{ppm})$ being the negative and positive controls, respectively. For each treatment, 60 seeds of $A$. серa (Baia Periforme variety; ISLA ${ }^{\circledR}$ ) were placed in a Petri dish with germitest paper. Dishes containing the seeds were treated with FDAE solutions and maintained in a BOD incubator at $25 \pm 2{ }^{\circ} \mathrm{C}$ with a photoperiod control (12 L:12 N ) for $96 \mathrm{~h}$. The visible radicle was measured with a Digimess ${ }^{\circledR}$ digital caliper passed $96 \mathrm{~h}$ after of the germination onset. The parameters used to define the toxicity effects of the extract were the percentages of Relative Seed Germination (RSG), Relative Root Growth (RRG) and Germination Index (GI) which were calculated using the formula described by HOEKSTRA et al. (2002) and WALTER et al. (2006). Roots $1.5 \mathrm{~cm}$ long were placed on a Carnoy's solution [ethanol and acetic acid $(3: 1 \mathrm{v} / \mathrm{v})]$ for $24 \mathrm{~h}$, washed $3 \mathrm{x}$ with distilled water, hydrolyzed with $1 \mathrm{~N} \mathrm{HCl}$ at $60^{\circ} \mathrm{C}$ for $10 \mathrm{~min}$ in a water bath, and washed again with distilled water. After another round of washing, they were stained in Schiff's reagent using Feulgen's method (ALEXANDER et al., 1950) for $1 \mathrm{~h} 30 \mathrm{~min}$. After staining, root meristems were covered with a coverslip and slightly smashed in a drop of $45 \%$ acetic carmine. For each treatment, 5 slides were prepared and photographed using the Binocular E100 (Nikon) optical microscope at a 400x magnification, such that 1,000 cells were checked per slide, resulting in a total of 5,000 cells. The cytotoxic potential was based on mitotic index (MI), and cell death index (CDI). The chromosomal alterations index (CAI) was evaluated by counting chromosome alterations (nuclear budding, C-metaphase, chromosomal loss, multipolar anaphases, chromosomal breaks, lobed nuclei and chromosomal bridges), and micronuclei were used to calculate mutagenicity indices (MTI). Cytotoxicity and genotoxicity potentials were calculated using the formula described by FRANCISCO et al., 2018.

\section{Statistical analyses}

The Kruskal-Wallis test and Dunn's post test were used to compare negative control and treatment groups in the cytotoxicity and genotoxicity assay, and the analysis of variance (ANOVA) test and Tukey post test were used for the tests involving the Relative Seed Germination (RSG), Relative Root Growth (RRG) and Germination Index (GI) $(\alpha=0.05)$. All analyses were conducted using the $\mathrm{R}$ statistical software (R DEVELOPMENT CORE TEAM, 2018). $\mathrm{LD}_{50}$ value was derived using the technique described by MEYER et al., 1982, which consists of obtaining a straight line by means of logarithmic transformation, followed by linear regression analysis.

\section{Ferric reducing antioxidant power (FRAP)}

The antioxidant potential of FDAE was evaluated in 5 concentrations $(67,401,668,1,336$, and $2,000 \mu \mathrm{g} / \mathrm{mL}$ ), in triplicate, using the FRAP method (EMBRAPA, 2006). Two hundred and seventy microliters of distilled water was initially added in to each test tube containing $90 \mu \mathrm{L}$ of the test solution or distilled water (blank), followed by $2.7 \mathrm{~mL}$ of the FRAP reagent. The samples were homogenized in a vortex, incubated in a water bath at $37{ }^{\circ} \mathrm{C}$ for $30 \mathrm{~min}$, and their respective absorbencies measured at $595 \mathrm{~nm}$. Aqueous solutions of ferrous sulfate heptahydrate were used to construct a calibration curve in the concentration range of $500-2,000 \mu \mathrm{M}$, and the FRAP value was expressed as $\mu \mathrm{M} \mathrm{Fe} / \mathrm{g}$.

\section{Phytochemical analyses \\ Total phenolic compounds}

The total phenolic content was determined following the method described by DJERIDANE et al. (2006). Briefly, $100 \mu \mathrm{L}$ of the infusion $(2 \% \mathrm{w} / \mathrm{v})$ was added to $1,000 \mu \mathrm{L}$ ultrapure water and $500 \mu \mathrm{L}$ Folin-Ciocalteu's reagent $(1 / 10)$ in water. After 1 min, $1,500 \mu \mathrm{L} \mathrm{Na}_{2} \mathrm{CO}_{3}(20 \% \mathrm{w} / \mathrm{v})$ was added. The final mixture was homogenized, and incubated for $2 \mathrm{~h}$ in the dark. The absorbance was read using a spectrophotometer (FENTO 700 PLUS) $(\lambda=760 \mathrm{~nm})$. Gallic acid from Sigma-Aldrich (USA) was used as a standard at concentrations ranging from 10-100 $\mu \mathrm{g} / \mathrm{mL}$. The results were expressed as $\mathrm{mg} \mathrm{GAE} / \mathrm{g}$ (GAE: gallic acid equivalent).

\section{Tannin content}

The condensed tannins were quantified by the vanillin-HCl method (BROADHURST \& JONES, 1978; AGOSTINI-COSTA et al., 1999) and expressed in $\mathrm{mg}$ of catechin by $\mathrm{g}$ of FDAE. Briefly, an aliquot of $4 \mathrm{~mL}$ of a methanol solution of vanillin $(4 \%)$ and $\mathrm{HCl}$ $(8 \%)$ was heated in a water bath at $30{ }^{\circ} \mathrm{C}$ for $30 \mathrm{~min}$. To preheated aliquot was added $1 \mathrm{~mL}$ of infusion to $2 \%$, the mixture obtained was maintained at $30{ }^{\circ} \mathrm{C}$ for 
another $20 \mathrm{~min}$, and then their absorbency measured at $500 \mathrm{~nm}$. Catechin was used to plot a calibration curve at the concentrations ranging from $2.5-40 \mu \mathrm{g} / \mathrm{mL}$ and estimate the condensed tannin content in the infusion of A. triangularis leaves.

\section{RESULTS AND DISCUSSION}

FDAE caused mortality on A salina, with an $\mathrm{LD}_{50}$ of $370.6 \pm 47.3 \mu \mathrm{g} / \mathrm{mL}$, being classified as moderately toxic (MEYER et al., 1982; AMARANTE et al., 2011). Although the occurrence of aristolochic acids and 1 aristolactam was hitherto described in leaves of an $A$. triangularis specimen cultivated at the botanical garden at Dresden University of Technology, Dresden, Germany (MICHL et al., 2016), the compounds responsible for the larval mortality observed in our study remain unknown. However, studies verifying the toxicity of FDAE highlight the need for careful consumption of teas from A. triangularis leaves, independent of their metabolomic profile.

To investigate the risks associated with the consumption of the infusion of $A$. triangularis leaves, the mutagenic, cytotoxic, and genotoxic activities of FDAE were equally evaluated by the A. cepa bioassay. The percentages of Relative Seed Germination (RSG), Relative Root Growth (RRG) and Germination Index (GI) are presented in table 1. Relevant statistical differences in GI were observed between the negative control and the concentration $2,000 \mu \mathrm{g} / \mathrm{mL}$. Because a $51.26 \%$ reduction was observed in the GI of $A$. cepa seeds, the toxicity of FDAE was confirmed, besides the existing evidence of their allelochemical potential. At all concentrations the RSG of the treated groups was statistically different from that of the negative control groups.
It can, therefore, be affirmed that the FDAE inhibits root growth at all concentrations.

Concordantly, the MI obtained after FDAE treatment of $A$. cepa seeds indicated cytotoxic action on the cell cycle at 668 and $2,000 \mu \mathrm{g} / \mathrm{mL}$ (Table 2). Antimitotic action was initially reported for a decoction of secondary growth stems from A. triangularis, with MI exhibiting a statistically relevant value in relation to the controls (AMAT et al., 2002). For the CDI, CAI and MTI no significant difference was observed between the treatment and negative control groups. The genotoxic and mutagenic effects were not observed at any concentration of FDAE when compared with the negative control group (Tables 1 and 2). Though not statistically significant, the main genetic alterations found were chromosome bridges, chromosomic loss, nuclear budding, and lobed nuclei.

These results further confirm the need for special attention by the World Health Organization (WHO) in discouraging the use of Aristolochia for medicinal purposes (MICHL et al., 2016; JADOT et al., 2017). Acquiring extensive knowledge on the therapeutic potential and risks of consuming $A$. triangularis will require further studies, specifically on pharmacological biosafety, as this species is one of Brazil's most cited plants in the ethnopharmacological sector.

Although the FDAE had some level of toxicity, it exhibited a considerable ferric reducing power, with a FRAP value of $391.1 \pm 1.2 \mu \mathrm{M} / \mathrm{g}$ (FERNANDES et al., 2016). This is in line with already existing studies demonstrating that plant extracts from members of the Aristolochia genus possess antioxidant properties. Such species include: Aristolochia bracteata, Aristolochia bracteolata, Aristolochia brasiliensis, Aristolochia clematitis, Aristolochia giberti, Aristolochia indica, Aristolochia

Table 1 - Relative Seed Germination (RSG), Relative Root Growth (RRG) and Germination Index (GI) of the aqueous extract from $A$. triangularis leaves upon the cell cycle of $A$. cepa meristems.

\begin{tabular}{lccc}
\hline $\mathrm{TR}(\mu \mathrm{g} / \mathrm{mL})$ & $\mathrm{RSG} \%$ & $\mathrm{RRG} \%$ & $\mathrm{GI}(\%)$ \\
\hline $\mathrm{NC}$ & $100.00 \pm 0.00$ & $100.00 \pm 0.00$ & $100.00 \pm 0.00$ \\
2000 & $76.19 \pm 0.00^{*}$ & $63.97 \pm 25.57$ & $48.74 \pm 19.49^{*}$ \\
668 & $79.34 \pm 0.00^{*}$ & $75.81 \pm 30.23$ & $60.17 \pm 24.00$ \\
401 & $82.54 \pm 0.00^{*}$ & $88.57 \pm 30.00$ & $72.11 \pm 24.76$ \\
67 & $82.54 \pm 0.00^{*}$ & $97.73 \pm 23.99$ & $80.66 \pm 19.80$ \\
$\mathrm{PC}$ & $76.19 \pm 0.00^{*}$ & $67.54 \pm 19.31$ & $51.46 \pm 14.71^{*}$ \\
\hline
\end{tabular}

TR: Treatments; PC: Positive control (Trifluralin 0.84 ppm); NC: Negative control (deionized water); ${ }^{*}$ Significantly different in relation to the negative control. 
Table 2 - Median of mutagenic, genotoxic and cytotoxic potentials of the aqueous extract from $A$. triangularis leaves upon the cell cycle of $A$. cepa meristems.

\begin{tabular}{lcccc}
\hline TR $(\mu \mathrm{g} / \mathrm{mL})$ & MI \% & CAI \% & MTI \% & CDI \% \\
\hline $\mathrm{NC}$ & $79.51 \mid 2.15$ & $0.10 \mid 0.22$ & $0.00 \mid 0.05$ & $0.00 \mid 0.02$ \\
2000 & $60.51 \mid 1.58^{*}$ & $0.15 \mid 0.19$ & $0.49 \mid 1.03$ & $0.00 \mid 0.02$ \\
668 & $63.42 \mid 6.82^{*}$ & $0.14 \mid 0.17$ & $0.00 \mid 0.00$ & $0.00 \mid 0.02$ \\
401 & $70.67 \mid 2.17$ & $0.05 \mid 0.19$ & $0.00 \mid 0.08$ & $0.00 \mid 0.06$ \\
67 & $70.42 \mid 5.32$ & $0.05 \mid 0.12$ & 0.02 & $0.00 \mid 0.05$ \\
PC & $44.76 \mid 12.12^{*}$ & $6.28 \mid 2.34^{*}$ & $2.80 \mid 0.92^{*}$ & $0.41 \mid 1.14^{*}$ \\
\hline
\end{tabular}

TR: Treatment; MI: Mitotic index; CAI: Chromosomal alteration index; MTI: Mutagenicity index; CDI: Cell death index; PC: Positive control (Trifluralin $0.84 \mathrm{ppm}$ ); NC: Negative control (distilled water); ${ }^{*}$ Significantly different in relation to the negative control.

krisagathra, Aristolochia longa, Aristolochia ringens, and Aristolochia tagala (VELÁZQUEZ et al., 2003; THIRUGNANASAMPANDAN et al., 2008; ANGALAPARAMESWARI et al., 2009; ANILKUMAR et al., 2014; BENMEHDI et al., 2017; MEROUANI et al., 2017; OBONGA et al., 2017).

The FDAE antioxidant potential observed can be attributed partly to the presence of tannins, and mainly to the high total phenolic content, since quantitative phytochemical analyses revealed the content of these compounds in FDAE as $0.02 \pm 0.01$ and $52.67 \pm 0.13 \mathrm{mg} / \mathrm{g}$, respectively. These values are in conformity with what was expected for an Aristolochia sp., provided that species belonging to this genus are rich sources of flavonoids, particularly diglycosides, and other phenolic chemical constituents, mainly phenylethyl and phenanthrene derivatives, phenylpropanoids, lignoids, alkamides, and alkaloids (LOPES et al., 2001; NOGUEIRA \& LOPES, 2012).

\section{CONCLUSION}

The aqueous extract of $A$. triangularis leaves exhibited toxicity and cytotoxicity in the $A$. salina and $A$. cepa bioassays, while simultaneously exhibiting a ferric reducing ability. The toxicological properties observed, indicate the need to be more cautious in the consumption of infusions from $A$. triangularis leaves, for medicinal purposes.

\section{ACKNOWLEDGEMENTS}

The authors would like to thank the FUNDECT - Fundação de Apoio ao Desenvolvimento do Ensino, Ciência e Tecnologia do Estado de Mato Grosso do Sul, and CNPq Conselho Nacional de Desenvolvimento Científico e Tecnológico for financial support. The MSc. Joelcio Freitas for botanical identification. J. D. A. da Silva thanks CAPES - Coordenação de Aperfeiçoamento de Pessoal de Nível Superior for a fellowship.

\section{DECLARATION OF CONFLICT OF INTERESTS}

The authors declare no conflict of interest. The founding sponsors had no role in the design of the study; in the collection, analyses, or interpretation of data; in the writing of the manuscript, and in the decision to publish the results.

\section{AUTHORS' CONTRIBUTIONS}

JDAS, CRN, SCHV, and CALC designed the study and executed the experiments: extract preparation, quantitative chemical analyses, and bioassays; MCV cultivated and processed the plant; ABG, BAC, LFV, and LFVF performed the A. cepa assay and the statistical analyses. The authors contributed equally to the manuscript.

\section{REFERENCES}

AGOSTINI-COSTA, T. S. et al. Avaliação de metodologias para determinação de taninos no suco de caju. Boletim CEPPA, v.17, n.2, p.167-176, July/Dec. 1999. Available from: <https://revistas. ufpr.br/alimentos/article/view/13789>. Accessed: Sep. 09, 2018. doi: 10.5380/cep.v17i2.13789.

ALEXANDER, J. et al. Rapid method of preparing Schiff reagent for the Feulgen test. Science, v.111, n.2871, p.13. Jan. 1950. Available from: <https://science.sciencemag.org/ content/111/2871/13.2>. Accessed: Apr. 22, 2019.

AMARANTE, C. B. et al. Estudo fitoquímico biomonitorado pelos ensaios de toxicidade frente à Artemia salina e de atividade antiplasmódica do caule de aninga (Montrichardia linifera). Acta Amazonica, v.41, n.3, p.431-434, 2011. Available from: <http://www. scielo.br/pdf/aa/v41n3/a15v41n3.pdf>. Accessed: Mar. 19, 2019.

AMAT, A. G. et al. Evaluation of cytological parameters induced by aqueous extracts of seven plants used as antihypertensive agents in Argentine folk medicine. Acta Farmacéutica Bonaerense, v.21, n.1, p.37-42, 2002. Available from: <http://sedici.unlp.edu.ar/ handle/10915/123/discover?query=amat\&filtertype_0=dateIssue 
d\&filtertype_1=type\&filter_relational_operator_1=equals\&filter relational operator $0=$ equals\&filter $-1=$ Articulo \&filter $0=\% 5 \bar{B}$ $2000+\mathrm{TO}+2006 \% 5 \mathrm{D} \&$ filtertype $=$ dateIssued \&filter_relational_ operator $=$ equals\&filter $=2002>$. Accessed: Sep. 09, 2018.

ANGALAPARAMESWARI, S. et al. Antimicrobial and antioxidant activity of root extract of Aristolochia bracteata Retz. The IUP Journal of Life Sciences, v.3, n.4, p.54-59, Nov. 2009. Available from: <https://papers.ssrn.com/sol3/papers cfm?abstract_id=1516178>. Accessed: Sep. 09, 2018.

ANILKUMAR, E. S. et al. A comparative study on in-vitro antioxidant, anticancer and antimicrobial activity of the methanol extracts of the roots of four species of Aristolochia L. from southern Western Ghats of India. International Journal of Advanced Research, v.2, n.12, p.153-164, 2014. Available from: <http:// www.journalijar.com/article/3196/a-comparative-study-on-invitro-antioxidant,-anticancer-and-antimicrobial-activity-of-themethanol-extracts-of-the-roots-of-four-species-of-aristolochia-1.from-southern-western-ghats-of-india/> . Accessed: Sep. 09, 2018.

BARROS, F. et al.. Aristolochiaceae. In: Lista de espécies da flora do Brasil. Jardim Botânico do Rio de Janeiro. 2015 Available from: $<$ http://floradobrasil.jbrj.gov.br/reflora/floradobrasil/FB15749>. Accessed: Aug. 29, 2018.

BENMEHDI, H. et al. Free radical scavenging activity, kinetic behavior and phytochemical constituents of Aristolochia clematitis L. roots. Arabian Journal of Chemistry, v.10, suppl.1, p.S1402-S1408, Feb. 2017. Available from: <https:// www.sciencedirect.com/science/article/pii/S1878535213001044> Accessed: Sep. 09, 2018. doi: 10.1016/j.arabjc.2013.04.015.

BROADHURST, R. B.; JONES, W. T. Analysis of condensed tannins using acidified vanillin. Journal of Science of Food and Agriculture, v.29, n.9, p.788-794, Sep. 1978. Available from: $<$ https:// onlinelibrary.wiley.com/doi/pdf/10.1002/jsfa.2740290908>. Accessed: Sep. 09, 2018. doi: 10.1002/jsfa.2740290908.

DJERIDANE, A. et al. Antioxidant activity of some algerian medicinal plants extracts containing phenolic compounds. Food Chemistry, v.97, n.4, p.654-660, 2006. Available from: <https:// www.sciencedirect.com/science/article/pii/S030881460500422X>. Accessed: Apr. 12, 2019. doi: 10.1016/j.foodchem.2005.04.028.

EMBRAPA. Metodologia científica: determinação da atividade antioxidante total em frutas pelo método de redução do ferro (FRAP). Fortaleza, 2006. 4p. Available from: <http://www.cnpat. embrapa.br/cd/jss/acervo/Ct_125.pdf>. Accessed: Mar. 19, 2019. ISSN 1679-6535.

FERNANDES, R. P. P. et al. Evaluation of antioxidant capacity of 13 plant extracts by three different methods: cluster analyses applied for selection of the natural extracts with higher antioxidant capacity to replace synthetic antioxidant in lamb burgers. Journal of Food Science and Technology, v.53, n.1, p.451-460, Jan. 2016 Available from: <https://www.ncbi.nlm.nih.gov/pmc/articles/ PMC4711430/pdf/13197_2015_Article_1994.pdf $>$. Accessed: Apr. 01, 2019. doi: 10.1007/s13197-015-1994-X.

FRANSCISCO, L. et al. Cytotoxicity, genotoxicity and mutagenicity of Aluminum, Manganese and Lead in Meristematic Cells of Root Allium cepa. Orbital: The Electronic Journal of Chemistry, v.10, p.60-65, Jan. 2018. Available from: <http:// www.orbital.ufms.br/index.php/Chemistry/article/view/1037>. Accessed: Oct. 09, 2018.
HEINRICH, M. et al. Local uses of Aristolochia species and content of nephrotoxic aristolochic acid 1 and 2-Aglobal assessment based on bibliographic sources. Journal of Ethnopharmacology, v.125, n.1, p.108-144, Aug. 2009. Available from: <https://www.sciencedirect. com/science/article/pii/S0378874109003468?via\%3Dihub>. Accessed: Aug. 28, 2018. doi: 10.1016/j.jep.2009.05.028.

HOEKSTRA, N.J. et al. Effects of cattle dung from farms with different feeding strategies on germination and initial root growth of cress (Lepidium sativun L.). Agriculture, Ecosystems \& Environment, v.93, n.1-3, p.189-196, Dec. 2002, Available from: <https://www. sciencedirect.com/science/article/pii/S0167880901003486>. Accessed: Apr. 22, 2019.

JADOT, I. et al. An integrated view of aristolochic acid nephropathy: update of the literature. International Journal of Molecular Sciences, v.18, n.2, p.297, Feb. 2017. Available from: $<$ https://www.ncbi.nlm.nih.gov/pmc/articles/PMC5343833/>. Accessed: Sep. 09, 2018. doi: 10.3390/ijms18020297.

LEITÃO, G. G. et al. Essential oils from Brazilian Aristolochia. Journal of Essential Oil Research, v.3, n.6, p.403-408, Nov./Dec. 1991. Available from: <https://www.tandfonline.com/doi/abs/10 .1080/10412905.1991.9697974>. Accessed: Aug. 30, 2018. doi: 10.1080/10412905.1991.9697974.

LIN, W. et al. Alkaloids from the roots of Aristolochia triangularis (I). Journal of Chinese Pharmaceutical Sciences, v.6, n.1, p.8-13, Jan. 1997. Available from: <http://118.145.16.238/Jwk_ zgyxen/EN/abstract/abstract786.shtml $>$. Accessed: Aug. 30, 2018.

LOPES, L. M. X. et al. Phytochemistry of the Aristolochiaceae family. In: Mohan R. M. M., editor. Research Advances in Phytochemistry, v.2. Kerala: Global Research Network, 2001. P.19-108.

LOPES, L. M. X. et al. Terpenes from Aristolochia triangularis. Phytochemistry, v.29, n.2,p.660-662, 1990. Available from: $<$ https:// www.sciencedirect.com/science/article/pii/0031942290851397>. Accessed: Aug. 30, 2018. doi: 10.1016/0031-9422(90)85139-7.

MATSUMOTOS.T.; MARIN-MORALESM.A. Toxic and genotoxic effects of trivalent and hexavalent chromium - a review. Revista Brasileira de Toxicologia, v.18, n.1, p.77-85, 2005. Available from: $<$ https://www.researchgate.net/publication/283502390 Toxic and genotoxic_effects_of_trivalent_and_hexavalent_chromium_-_A_ review>. Accessed: Apr. 11, 2019.

MEROUANI, N. et al. Evaluation of the biological activity of Aristolochia longa L. extracts. International Journal of Pharmaceutical Sciences and Research, v.10, p.19781992, May, 2017. Available from: <http://ijpsr.com/bftarticle/evaluation-of-the-biological-activity-of-aristolochialonga-1-extracts/>. Accessed: Sep. 09, 2018. doi: 10.13040/ IJPSR.0975-8232.8(5).1978-92.

MEYER, B. N. et al. Brine shrimp: a convenient general bioassay for active plant constituents. Planta Medica, v.45, n.5, p.31-35, Jan. 1982. Available from: <https://www.thieme-connect.com/ DOI/DOI?10.1055/s-2007-971236>. Accessed: Sep. 09, 2018. doi: $10.1055 / \mathrm{s}-2007-971236$.

MICHL, J. et al. LC-MS- and ${ }^{1} \mathrm{H}$ NMR-based metabolomic analysis and in vitro toxicological assessment of 43 Aristolochia species. Journal of Natural Products, v.79, n.1, p.30-37, 2016. Available from: <https://pubs.acs.org/doi/abs/10.1021/acs.jnatprod.5b00556>. Accessed: Aug. 30, 2018. doi: 10.1021/acs.jnatprod.5b00556. 
MONGELLI, E. et al. Cytotoxic and DNA interaction activities of extracts from medicinal plants used in Argentina. Journal of Ethnopharmacology, v.71, n.1-2, p.145-151, July 2000. Available from: <https://www.sciencedirect.com/science/article/ pii/S0378874199001956?via\%3Dihub>. Accessed: Aug. 30, 2018. doi: 10.1016/S0378-8741(99)00195-6.

MUSCHIETTI, L. et al. The anti-inflammatory effect of some species from South America. Phytotherapy Research, v.10, p.8486, Feb. 1996. Available from: $<$ https://onlinelibrary.wiley.com/doi/ epdf $/ 10.1002 / \% 28$ SICI $\% 291099-1573 \% 28199602 \% 2910 \% 3 \mathrm{~A} 1 \% 3$ C84\%3A\%3AAID-PTR779\%3E3.0.CO\%3B2-C > . Accessed: Aug. 30, 2018. doi: 10.1002/(SICI)1099-1573(199602)10:1<84::AIDPTR779>3.0.CO;2-C.

NOGUEIRA, C. R.; LOPES, L. M. X. Nitro derivatives and other constituents of Aristolochia melastoma. Química Nova, v.35, n.4, p.780-782, Jan. 2012. Available from: <10.1590/S010040422012000400024>. Accessed: Sep. 09, 2018. doi: 10.1590/ S0100-40422012000400024.

OBONGA, W. O. et al. Comparative phytochemical, antioxidant and antimicrobial properties of Ficus capensis, Aristolochia ringens, Albizia zygia and Lannea welwitschii. Dhaka University Journal of Pharmaceutical Sciences, v.16, n.2, p.147-157, Dec. 2017. Available from: <https:/www.banglajol.info/index. php/JPharma/article/view/35249>. Accessed: Sep. 09, 2018. doi: 10.3329/dujps.v16i2.35249.

OLIVEIRA, D. G. et al. Antimycobacterial activity of some Brazilian indigenous medicinal drinks. Revista de Ciências Farmacêuticas Básica e Aplicada, v.28, n.2, p.165-169, Dec. 2007. Available from: <http://200.145.71.150/seer/index.php/ Cien_Farm/article/viewArticle/321>. Accessed: Aug. 30, 2018.

PEREIRA, A. O. et al. Chemical composition, antimicrobial and antimycobacterial activities of Aristolochia triangularis Cham. from Brazil. Industrial Crops and Products, v.121, p.461-467, Oct. 2018. Available from: <https://www.sciencedirect.com/ science/article/pii/S0926669018304710>. Accessed: Aug. 28, 2018. doi: 10.1016/j.indcrop.2018.05.052.

PRIESTAP, H. A. et al. Investigation of the essential oils from Aristolochia triangularis. Journal of Essential Oil Research, v.2, n.3, p.95-98, May/June 1990. Available from: <https://www. tandfonline.com/doi/abs/10.1080/10412905.1990.9697836>. Accessed: Aug. 30, 2018. doi: 10.1080/10412905.1990.9697836.

R DEVELOPMENT CORE TEAM, R: A Language and Environment for Statistical Computing. R Foundation for Statistical
Computing, Vienna. (2018) Available from: <http://www.scirp. org/(S(351jmbntvnsjt1aadkposzje))/reference/ReferencesPapers. aspx?ReferenceID=1792512>. Accessed: Sep. 09, 2018.

RÜCKER, G. et al. 3,4-Dimethoxy-3,4-demethylenedioxycubebin, a new lignan from Aristolochia triangularis. Tetrahedron Letters, v.19, n.5, p.457-458, 1978. Available from: <https:// www.sciencedirect.com/science/article/pii/S0040403901914534>. Accessed: Aug. 30, 2018. doi: 10.1016/S0040-4039(01)91453-4.

RÜCKER, G. etal. Constituents of Aristolochiatriangularis. Planta Medica, v.41, n.2, p.143-149, Feb. 1981. Available from: $<$ https:// www.thieme-connect.com/DOI/DOI?10.1055/s-2007-971691>. Accessed: Aug. 30, 2018. doi: 10.1055/s-2007-971691.

SCHVARTZMAN, J. B. et al. Cytological effects of some medicinal plants used in the control of fertility. Experientia, v.33, n.5, p.663-665, May 1977. Available from: <https://link.springer. com/article/10.1007/BF01946562>. Accessed: Aug. 28, 2018. doi: 10.1007/BF01946562.

THIRUGNANASAMPANDAN, R. et al. Antioxidant properties of some medicinal Aristolochiaceae species. African Journal of Biotechnology, v.7, n.4, p.357-361, Feb. 2008. Available from: $<$ http://www.academicjournals.org/AJB $>$. Accessed: Sep. 09, 2018.

TROJAN-RODRIGUES, M. et al. Plants used as antidiabetics in popular medicine in Rio Grande do Sul, southern Brazil. Journal of Ethnopharmacology, v.139, n.1, p.155-163, Jan. 2012. Available from: <https://www.sciencedirect.com/science/article/ pii/S0378874111007732?via\%3Dihub>. Accessed: Aug. 28, 2018. doi: 10.1016/j.jep.2011.10.034.

VELÁZQUEZ, E. et al. Antioxidant activity of Paraguayan plant extracts. Fitoterapia, v.74, n.1-2, p.91-97, Feb. 2003. Available from: <https://www.sciencedirect.com/science/article/ pii/S0367326X02002939?via\%3Dihub>. Accessed: Sep. 09, 2018. doi: 10.1016/S0367-326X(02)00293-9.

VIBRANS, A. C. et al. Levantamento Socioambiental (LSA): Cipó-mil-homens (Aristolochia triangularis) - Mitos e verdades. In: Inventário Florístico Florestal de Santa Catarina (IFFSC). Available from: <https://sites.google.com/view/iffportal/ publica\%C3\%A7\%C3\%B5es/cartilhas $>$. Accessed: Aug. 28, 2018.

WALTER, I. et al. Heavy metal speciation and phytotoxic effects of three representative sewage sludges for agricultural uses. Environmental Pollution, v.139, p.507-514. Feb. 2006. Available from: <https://www.sciencedirect.com/science/article/ pii/S0269749105003143>. Accessed: Apr. 22, 2019. 